\title{
COMPARISON OF URBAN RETROFITTING SCENARIOS FOR SUSTAINABLE STORMWATER CONTROL: A CASE STUDY IN MILAN, ITALY
}

\author{
FRANCO RAIMONDI ${ }^{1,2}$, MARIANA LOBO MARCHIONI ${ }^{1}$, \\ ANITA RAIMONDI ${ }^{1} \&$ GIANFRANCO BECCIU ${ }^{1}$ \\ ${ }^{1}$ Politecnico di Milano, Italy \\ ${ }^{2}$ ERSAF, Italy
}

\begin{abstract}
The traditional approach of stormwater management in urban areas frequently affected by floods has proven to be unsustainable for the growing urbanization scenario as well as not adapted to provide climate change resilience. In the spirit of water sensitive cities, a stormwater management change is necessary, moving from pipe-based conveyance system to solutions able to manage at its source by small scale structures sprawled over the entire watershed, in a collection of systems and practices known as SuDs (Sustainable Urban Drainage Systems). These techniques provide several benefits not only related to risk mitigation but also to water quality and ecosystem services enhancement that make cities resilient also in terms of climate change. Currently stormwater and land use regulations mostly define a flow-limit to reduce discharge on the sewer systems. In this way, however, the search for further benefits is not encouraged. Flow-limit restrictions are obtained through storage control systems designed with design-storm methods that neglects the effect of pre-filling reducing the storage capacity before a new rainfall event. This research compares different stormwater management solutions for a new developed area located in Bresso municipality, in the metropolitan area of Milan (Italy), within the Seveso River watershed. The proposed scenarios go from no intervention to completely avoiding discharge on the sewer network with the implementation of stormwater control structures (permeable pavements, green roofs, retention basins, among others). The storage facilities are designed with a traditional design method and then their performance is evaluated with rainfall-runoff and routing model continuous simulations, also used to compare the different scenarios. The simulations confirm that is possible to reach more restrictive goals beyond the flow-limit regulations using stormwater controls structures that also provide multiple benefits and have significant effects in terms of hydraulic risk mitigation at watershed level. Continuous simulation shows that the effect of chained rainfall events can however reduce controls performance and should be considered when designing.

Keywords: urban retrofitting, spatial planning, sustainable drainage systems (SuDs), flood risk mitigation.
\end{abstract}

\section{INTRODUCTION}

Multiples impacts on environment and their communities come from urban sprawl. Urbanization affects the water cycle increasing hydraulic risk and contamination of watercourses. Land consumption increases runoff peak flow and volume and the multiple non-point source pollutants worsen water quality. The overloaded drainage system, including artificial and natural watercourse often underground, cause floods with significant human and economic damages.

The metropolitan area of Milan observed an expansion of the urban area driven by economic growth post-war. As the urban area increases, so did the number of flood events on the Seveso River, the main river that crosses Milan entirely by an underground route (Fig. 1). A by-pass channel built in 1982 discharging on the River Ticino reduced the flood events for a few years but lost effectiveness as the cities located upstream continued to develop. A study held on the Seveso River basin estimated that to reduce the flood events would be necessary to implement five detention basins with an estimated cost of 130 million Euros [1]. 


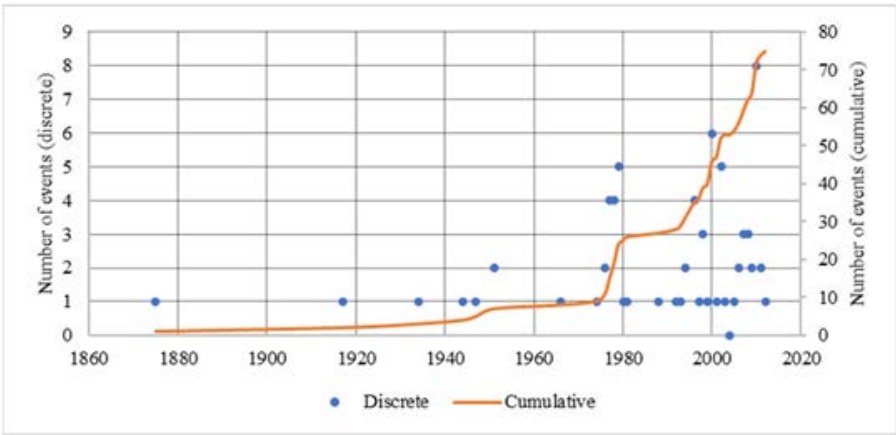

Figure 1: Flood events registered on the Seveso River from 1860.

The traditional approach relies on stormwater discharge to watercourses directly or through combined sewers overflows (CSOs) and large-scale infrastructures to manage flooding. This approach is unsustainable on the current urbanization growth scenario and it is preferable to manage stormwater through the reproduction of natural processes of storage, infiltration and evapotranspiration through small-scale control infrastructures. These smallscaled control structures can efficiently reduce runoff peak flow and volume with several benefits incorporated, such as biodiversity opportunities, heat island mitigation, amenities. In an effort to mitigate flood risk following this philosophy the Lombardy region, where the metropolitan Milan is located, developed in 2017 a policy on stormwater management to new constructions and major retrofits (RR7-2017) [2]. The text includes flow-limits and mandatory storage facilities establishing minimum values and suggesting design methods. The regulation, however, does not include measures to encourage the additional benefits from small-scale control structures, although it mentions that water harvesting for reuse and infiltration should be encouraged.

Design procedure for control storage facilities normally uses a design storm event approach. Lombardy regulation suggests a simple method to obtain preliminary results for small catchments areas. This method considers inflow as the net water depth from IntensityDuration-Frequency equation (IDF) and outflow as the outlet and soil infiltration rate, neglecting rainfall-runoff transformation. These preliminary results should be confirmed with routing calculations using computational models. An alternative approach is to adopt a probabilistic analytical method that provides long-term simulation accuracy with a simple and low computational effort. This approach has been applied to control storage systems by various authors with good correlation when compared with continuous simulation [3]-[8].

Previous research undertaken by the authors studied the hydrological response on flood area reduction by implementing ecological buffers on a stretch of the Seveso River, Milan [9]. Encouraging source-area controls could provide further flood area reduction. To achieve this goal a retrofitting plan is proposed in an area located in the vicinity of the Seveso river to observe the runoff peak flow and volume reduction for different scenarios with the following systems: permeable pavements (PP), rain gardens (RG), bioretention cells (BC), green roof (GF) and a wetland. The control structures with storage (PP, BC) were designed with a design storm approach and have their performance analyzed with a rainfall-runoff routing model varying the Annual Recurrence Interval (ARI) (2, 10, 50 and 100-years storm) and with registered rainfall-data. The hydrological benefits of the different scenarios were also compared with the no-retrofit scenario. 


\section{CASE STUDY AREA}

The Bresso municipality is the most densely populated $\left(7,597\right.$ inhabitants $\left./ \mathrm{km}^{2}\right)$ in the metropolitan area of Milan. In 2019, the municipal administration of Bresso approved an urban redevelopment project that involves the increase of the existing social and health services. This project represents an opportunity to implement different source control systems (Tables 1 and 2) not only to comply with regional policies but also to provide combined benefits. Furthermore, in the watershed perspective and multidisciplinary approach pursued by the Seveso River Sub-basin Strategic Project [10], it could be the opportunity to take a forward step and realize a neighborhood in which all the stormwater is effectively treated and managed at its source without discharging into the sewer system. In particular, in the redevelopment area of 55,800 $\mathrm{m}^{2}$, the parking areas de-sealing, the construction of a green roof for a sport hall, the downspouts disconnection and finally the creation of a wetland $\left(1,600 \mathrm{~m}^{2}\right)$ are assumed.

Table 1: Retrofitting scenario description.

\begin{tabular}{|c|l|c|c|}
\hline \multirow{2}{*}{ ID } & \multirow{2}{*}{ Scenario } & \multicolumn{2}{|c|}{ Impervious area } \\
\cline { 3 - 4 } & & $\left(\mathrm{m}^{2}\right)$ & $(\%)$ \\
\hline A & Current state & 23,290 & 43.4 \\
\hline B & New developments without control systems & 25,894 & 48.3 \\
\hline S1 & Permeable pavements (all parking area) & 19,965 & 37.2 \\
\hline S2 & Bioretention-cells (10\% of impervious area) & 25,059 & 46.7 \\
\hline S3 & Rain gardens (10\% of impervious area) & 25,059 & 46.7 \\
\hline S4 & PP, GF, BC, RG & 17,568 & 32.7 \\
\hline S5 & only wetland & 25,894 & 48.3 \\
\hline S6 & PP, GF, BC, RG + wetland & 17,568 & 32.7 \\
\hline
\end{tabular}

Table 2: Percentage surface occupied by controls structures respect to the total impervious area $\left(25,894 \mathrm{~m}^{2}\right)$ for each scenario.

\begin{tabular}{|l|c|c|c|c|c|c|}
\hline \multirow{2}{*}{ Control structures } & \multicolumn{7}{|c|}{ Scenario } \\
\cline { 2 - 8 } & S1 & S2 & S3 & S4 & S5 & S6 \\
\hline Permeable pavements & 22.9 & - & - & 22.9 & - & 22.9 \\
\hline Bioretention-cells & - & 10 & - & 3.3 & - & 3.3 \\
\hline Rain gardens & - & - & 10 & 1.6 & - & 1.6 \\
\hline Green roofs & - & - & - & 8.7 & - & 8.7 \\
\hline Presence of wetland & No & No & No & No & Yes & Yes \\
\hline
\end{tabular}

A brief description of the main characteristics of the Suds techniques considered in retrofitting scenarios are summarized below.

Permeable pavement (PP) allows water infiltration through its their surface into the underlying layer infiltrating or discharging through a drainage pipe towards the next system promoting runoff volume, peak flow and load reduction [11].

Green roofs (GF) consist of multiple layers (filter fabric and growing medium layer, water-proof membrane, mechanic protection geotextile, drainage layer) able primarily to retain rainwater and delaying its release [12]. 
Rain gardens and bioretention cells consist of a vegetated surface layer and a filter media within which the filtering water from roofs, roads and parking areas is treated.

Wetlands are shallow and deep water areas, with the main function to store stormwater for extended periods to facilitate sediments settling and water depuration [13].

\section{METHODOLOGY}

Three types of comparisons for the scenarios were investigated. The first type of comparison considered each scenario described in Tables 1 and 2 and involved a 24-h duration and onein-2-year, one-in-10-year, one-in-50-year and one-in-100-year storm. Results are reported in Tables 4 and 5. In particular, the analysis of control structures performance, in urban retrofitting scenarios (S1, S2, S3, S4 and S6), for the one-in-50-year event are shown in Table 6. Scenario 5 is not reported due to the absence of Suds techniques implementation.

The second type of comparison concerned only scenario 1 and scenario 2, which include $\mathrm{PP}$ and BC, respectively. A 2-h critical rainfall durations of for PP and of $14 \mathrm{~h}$ for BC were considered. These durations were calculated using the storm design approach. The scenarios were then compared for one-in-2-year, one-in-10-year and one-in-50-year event. Results are presented in Tables 7 and 8 .

The last comparison was carried out by using two continuous time series (year 2015 and November-December/2014). In this case scenarios 5 and 6 were not considered. Results are shown in Tables 9 and 10 and in Fig. 2 for year 2015, in Tables 11 and 12 and in Fig. 3 for November-December/2014.

\subsection{Design-storm approach}

The design-storm approach is traditionally used to design control structures that temporarily stores rainfall. A simple design procedure that provides a preliminary estimation consists of finding the critical design-storm, in this case the one that yields the maximum volume considering the water inflow and outflow. The inflow represents the net rainfall depth from the site I-D-F (Intensity-Duration-Frequency) equation and outflow represents the soil infiltration rate and outlets. The maximum water depth, that leads to maximum volume, is obtained through the derivation of the inflow and outflow curves. For infiltration systems, without considering the outlet, the critical storm duration $\left(\theta_{c}\right)$ can be obtained with eqn (1), and the water depth $(h)$ with eqn (2). This method considers a rectangular hyetograph and neglects the rainfall-runoff transformation.

The method does not consider the effect of pre-filling [14], where the control system is partially full at the beginning of the rainfall event and in the case of a series of rainfall events. To minimize the risk of pre-filling a limit of $48 \mathrm{~h}$ to completely empty the structure, obtained with eqn (3), is recommended.

$$
\begin{gathered}
\frac{d h}{d \theta}=\varphi \cdot a \cdot n \cdot R \cdot \frac{\theta^{n-1}}{p}-\frac{f_{c}}{p}=0 \rightarrow \theta_{w}=\left(\frac{f_{c}}{\varphi \cdot a \cdot n \cdot R}\right)^{\frac{1}{n-1}}, \\
h=h\left(\theta_{w}\right)=\frac{\theta_{w_{1}}}{p} \cdot\left(\varphi \cdot a \cdot \theta^{n-1} \cdot R-f_{c}\right), \\
t_{e m p}=\frac{p \cdot h}{f_{c}},
\end{gathered}
$$

where $\varphi$ stands for the runoff coefficient, $a$ and $n$ are the parameters of an IDF $h=a \theta^{n} ; R$ the ratio between the catchment area that discharges on the structure $\left(A_{c}\right)$ and the area available for infiltration $\left(A_{i}\right)$ where $R=A_{c} / A_{i} ; \theta$ is the rainfall duration, $f_{c}$ is the soil infiltration capacity in $\mathrm{mm} / \mathrm{h}, p$ is the filling material porosity, $h$ is the structure depth for a given area and $t_{\text {emp }}$ is the emptiness time. The following IDF parameters were used: 2-years storm $-\mathrm{a}=30 \mathrm{~mm} / \mathrm{h}^{\mathrm{n}}$; 
10 -years storm $-\mathrm{a}=47 \mathrm{~mm} / \mathrm{h}^{\mathrm{n}} ; 50$-years storm $-\mathrm{a}=63 \mathrm{~mm} / \mathrm{h}^{\mathrm{n}} ; 100$-years storm $-\mathrm{a}=70$ $\mathrm{mm} / \mathrm{h}^{\mathrm{n}}$. For all return periods $\mathrm{n}=0.31$.

This procedure was used to design the PP for a one-in-50-year design storm, according to the regional regulation, concomitantly with a structural design using the AASHTO mechanistic-empirical method. The BC was design for a one-in-2-year storm since this structure typically manages small storms, discharging the excess through a spillway. Considering that the Bresso municipality has a sand-gravel soil the infiltration rate estimate was $3.33 \times 10^{-6} \mathrm{~m} / \mathrm{s}(12 \mathrm{~mm} / \mathrm{h})$. The method was not applied to GF and RG where typical thickness where adopted, while the wetland maintained an existing design by the municipality.

\subsection{Rainfall-runoff model}

The preliminary results obtained with the design-storm approach were checked by performing routing calculations using a rectangular storm with 24-h duration and 2, 10, 50 and 100 years-storm. The storm shape and duration selection means to yield maximum volume. A continuous simulation was also undertaken with registered rainfall data from 2015 considered a typical hydrological year, and with November-December from 2014, when a major flood event was registered in the Seveso River. The storage routing was undertaken using the USEPA-SWMM (United States Environmental Protection Agency - Storm Water Management Model). SWMM is a dynamic rainfall-runoff simulation model used for single event or long-term (continuous) simulation of runoff quantity and quality from primarily urban areas. The runoff component of SWMM operates on a collection of subcatchment areas that receive precipitation and generate runoff and pollutant loads. The routing portion of SWMM transports this runoff through a system of pipes, channels, storage/treatment devices, pumps, and regulators. SWMM tracks the quantity and quality of runoff generated within each subcatchment, and the flow rate, flow depth, and quality of water in each pipe and channel during a simulation period comprised of multiple time steps [15]. The processes modelled were rainfall-runoff and flow routing using kinematic wave, Horton infiltration model and the control structures with LID block option. Ponding and discharge from control structures were observed to verify the systems performance. The parameters adopted for the controls structures were based on the preliminary results obtained with the storm-design approach. The criteria used to compare scenarios considered peak flow, lag time and volume.

\section{RESULTS AND DISCUSSION}

The PP with storm-design approach resulted in a storage layer thickness of $h=102 \mathrm{~mm}$ for a rainfall duration of $\theta_{c}=2 \mathrm{~h}$ and emptiness time $t_{\text {emp }}=4 \mathrm{~h}$. Structural design considering vehicular traffic resulted in a thickness $h=300 \mathrm{~mm}$, being the critical thickness adopted. For a one-in-a-100-years storm $h=120 \mathrm{~mm}$, within the thickness selected for the PP.

The $\mathrm{BC}$ storage layer equals $h=1,074 \mathrm{~mm}$ for a rainfall duration of $\theta_{c}=14 \mathrm{~h}$ and emptiness time $t_{e m p}=31 \mathrm{~h}$. Notice that a one-in-50-years storm would require a BC with $h=$ 3,148 $\mathrm{mm}$ and $t_{\text {emp }}=91 \mathrm{~h}$. The storage layers thickness obtained with the design-storm approach were used for the rainfall-runoff simulations, the other parameters were obtained following typical values (Table 3 ).

Volume and peak flow obtained with the rainfall-runoff model for a one-in-24-h storm duration and constant rainfall intensity (rectangular storm) for the current scenario (A), postintervention (B) and the retrofitting with stormwater controls are presented in Table 4. The hydrologic performance comparing the initial scenario (A) with the post-retrofitting scenario 
Table 3: LID parameter for rainfall-runoff simulations.

\begin{tabular}{|l|c|c|c|c|}
\hline Control simulation parameters & PP & GF & RG & BC \\
\hline Surface & 2.5 & 75 & 300 & 300 \\
\hline Berm height [mm] & 0.0 & 0.2 & 0.15 & 0.15 \\
\hline Vegetation volume fraction [\%] & 0.1 & 0.3 & 0.3 & 0.3 \\
\hline Roughness & 0.5 & 0.5 & 0.5 & 0.5 \\
\hline Slope [\%] & 100 & - & - & - \\
\hline Pavement layer & 0.2 & - & - & - \\
\hline Thickness [mm] & 1,000 & - & - & - \\
\hline Void ratio & 200 & 150 & 1,200 & 1,200 \\
\hline Permeability [mm/h] & 0.3 & 0.6 & 0.52 & 0.52 \\
\hline Soil layer & 0.2 & 0.45 & 0.25 & 0.25 \\
\hline Thickness [mm] & 0.05 & 0.05 & 0.05 & 0.05 \\
\hline Porosity & 750 & 10 & 110 & 110 \\
\hline Field capacity & 300 & - & - & 900 \\
\hline Wilting point & 0.5 & - & - & 0.35 \\
\hline Conductivity [mm/h] & 12 & - & 12 & 12 \\
\hline Storage layer & \\
\hline Thickness [mm] & Void ratio & & \\
\hline Seepage rate [mm/h] & \multicolumn{5}{|l|}{} \\
\hline
\end{tabular}

Table 4: Volume and peak flow for a $24 \mathrm{~h}$ duration storm for different scenarios (ARI $=2$, 10,50 and 100 years).

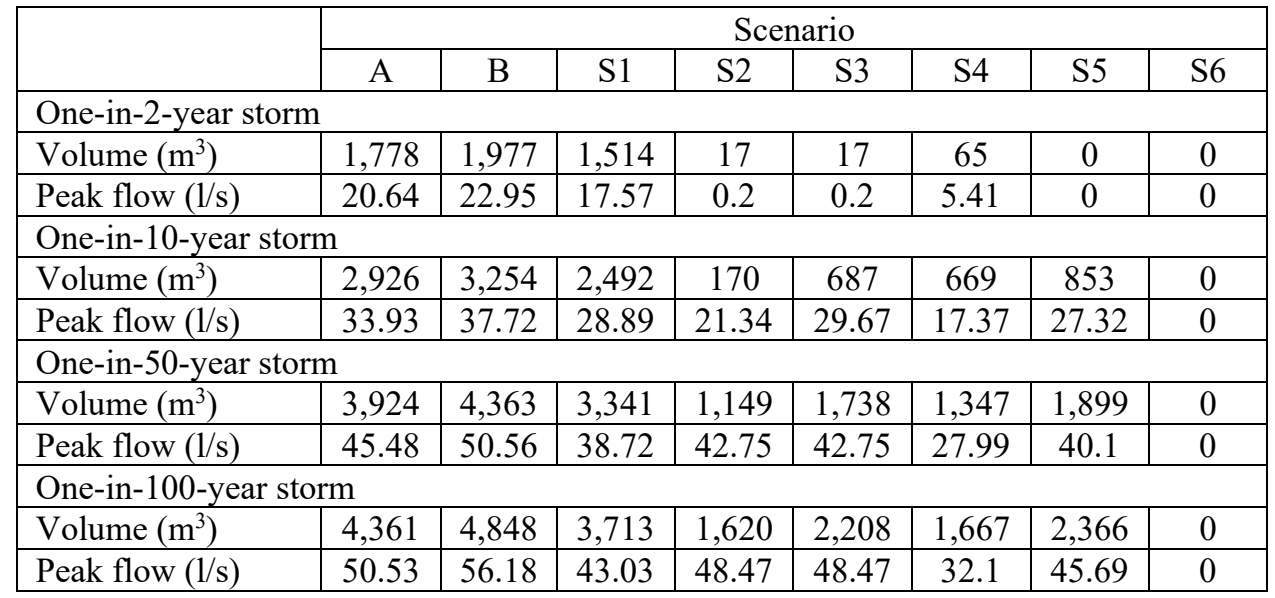

(S1-6) is shown on Table 5. The scenario S6, with a combination of controls systems and a wetland, manages to retain all stormwater for all ARI. Local regulation establishes a flowlimit of $10 \mathrm{l} / \mathrm{s} / \mathrm{ha}_{\text {imp }}$ for the Bresso municipality, resulting in a total allowed flow of $23 \mathrm{l} / \mathrm{s}$ for the current scenario (SA) and $26 \mathrm{l} / \mathrm{s}$ for the post-interventions (SB). 
Table 5: Hydrologic performance of the retrofit scenarios for a $24 \mathrm{~h}$ duration storm at the assigned return period (ARI $=2,10,50$ and 100 years).

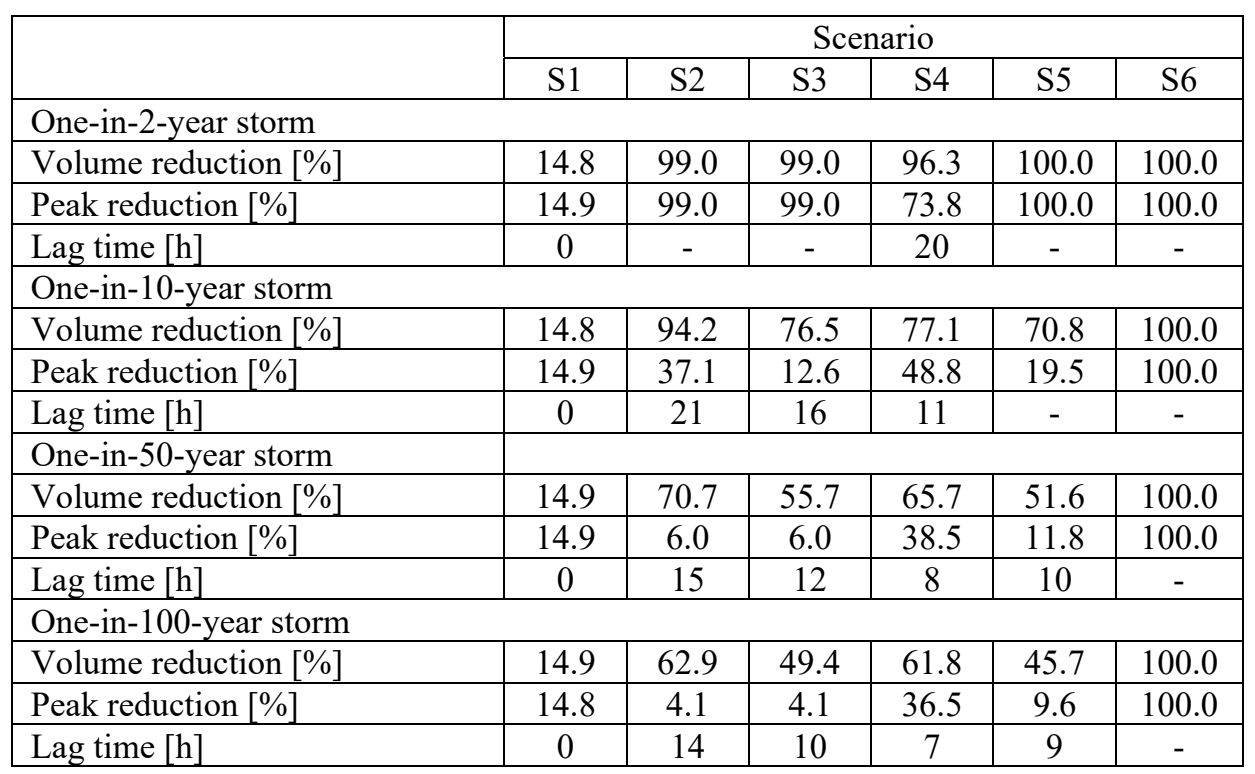

The controls performance parameters for a one-in-50-year storm are presented in Table 6 . When the depth of ponded water is above the maximum storage level then surface outflow occurs, outflow reduction performance compares inflow and surface outflow. When the control structures are considered individually, PP (S1) represent the best alternative because show no outflow for the one-in-50-year event. Instead, when the overall runoff volume is considered, scenarios with combined control structures (S2, S3, S4 and S6) are the best solutions. A pre-filling (initial storage) was considered for the storage facilities and for all scenarios. After the rainfall event, control structures were partially full (final storage) and the runoff probability could increase if an event occurs without completely emptying the structure.

Table 6: Stormwater controls performance for retrofitting scenarios for one-in-50-year storm.

\begin{tabular}{|l|c|c|c|c|c|}
\hline & S1 & S2 & S3 & S4 & S6 \\
\hline Total inflow (mm) & 506 & 16,771 & 16,771 & 23,156 & 23,156 \\
\hline Surface outflow (mm) & 0 & 4,086 & 6,363 & 10,129 & 10,129 \\
\hline Outflow reduction (\%) & 100 & 76 & 62 & 56 & 56 \\
\hline Infiltration loss (mm) & 416 & 3,459 & 3,459 & 3,656 & 3,656 \\
\hline Initial storage (mm) & 30 & 600 & 600 & 578 & 578 \\
\hline Final storage (mm) & 115 & 9,810 & 7,533 & 9,821 & 9,821 \\
\hline
\end{tabular}

The rainfall-runoff and routing simulation was also held with the storm duration obtained with the storm-design approach for PP (S1) and BC (S2) with a rectangular shape storm (Table 7). The S1 exceeds the regional flow-limit (25.89 1/s) for all storms ARI, while for S2 only for one-in-50-year storm. Considering that the regional regulation establishes a one-in- 
50-year storm additional control structures should be include for both S1 and S2. Storms with 2-years and 10-years ARI were completely manage by the controls with residual water depth after the end of the rainfall event (Table 8).

Table 7: Volume and peak flow routing simulation results for a storm duration $\left(\theta_{c}\right)$ obtained with the storm-design method (ARI $=2,10$ and 50 years).

\begin{tabular}{|l|c|c|}
\hline & \multicolumn{2}{|c|}{ Scenario } \\
\hline & $\mathrm{S} 1$ & $\mathrm{~S} 2$ \\
\hline$\theta_{c}$ (hours) & 2 & 14 \\
\hline 2 years return period event & & \\
\hline Volume $\left(\mathrm{m}^{3}\right)$ & 704 & 0 \\
\hline Peak flow $(1 / \mathrm{s})$ & 98.7 & 0 \\
\hline 10 years return period event & & \\
\hline Volume $\left(\mathrm{m}^{3}\right)$ & 1,149 & 0 \\
\hline Peak flow $(1 / \mathrm{s})$ & 160.46 & 0 \\
\hline 50 years return period event & & \\
\hline Volume $\left(\mathrm{m}^{3}\right)$ & 1,544 & 672 \\
\hline Peak flow $(1 / \mathrm{s})$ & 221.66 & 64.93 \\
\hline
\end{tabular}

Table 8: Stormwater controls performance for a storm duration $\left(\theta_{c}\right)$ obtained with the storm-design method s (ARI $=2,10$ and 50 years).

\begin{tabular}{|l|c|c|c|c|c|c|}
\hline ARI & \multicolumn{2}{|c|}{2 -years } & \multicolumn{2}{c|}{10 -years } & \multicolumn{2}{c|}{50 -years } \\
\hline & S1 & S2 & S1 & S2 & S1 & S2 \\
\hline Total inflow $(\mathrm{mm})$ & 107.52 & $6,445.28$ & 174.81 & $10,580.31$ & 234.3 & $14,187.52$ \\
\hline Surface outflow (mm) & 0 & 0 & 0 & 0 & 0 & $2,427.16$ \\
\hline Outflow reduction (\%) & 100 & 100 & 100 & 100 & 100 & 83 \\
\hline Infiltration loss (mm) & 17.34 & 858.06 & 68.88 & $1,364.07$ & 78.12 & $1,564.41$ \\
\hline Initial storage (mm) & 30 & 600 & 30 & 600 & 30 & 600 \\
\hline Final storage (mm) & 119.76 & $6,185.22$ & 136.11 & $9,812.44$ & 185.76 & $10,792.13$ \\
\hline
\end{tabular}

Table 9 presents volume and peak flow and Table 10 presents the controls performance for the continuous rainfall simulation for the year 2015 (Lambrate rain gauge station). The total rain depth for this year was $\mathrm{h}_{\text {tot }}=778 \mathrm{~mm}$ with $\mathrm{N}=54$ rainfall events for Inter Event Time Duration equals IETD $=6 \mathrm{~h}$ and Initial Abstractions IA $=2 \mathrm{~mm}$ resulting on an average depth of $\mu_{\mathrm{h}}=13 \mathrm{~mm}$, average duration $\mu_{\Theta}=14 \mathrm{~h}$ and average previous dry hours $\mu_{\mathrm{pdh}}=138$ h. Scenarios S5 and S6 where the outflow node is connected with a wetland did not produce runoff. The flow-limit is not met for both scenarios as for the PP (S1) scenario (Table 9). For the entire year PP (S1) did not generate surface outflow, but to meet regulations a combination with other controls systems is necessary to manage roof areas. The cumulative runoff volume increases $11 \%$ after the interventions planned for the area, while when adopting control structures cumulative volume reduces from the initial scenario $15 \%$ for $\mathrm{S} 1$ (PP), 99\% for S2 (BC), S3 (RG) and S4 (combined PP, BC, RG and GF) (Fig. 2). Controls manage inflow almost entirely with residual water depth on the storage facilities for all scenarios with exception of S1 (PP) (Table 10). 
Table 9: Volume and peak flow for continuous rainfall simulation (reference year: 2015).

\begin{tabular}{|l|c|c|c|c|c|c|}
\hline & \multicolumn{7}{|c|}{ Scenarios } \\
\hline & SA & SB & S1 & S2 & S3 & S4 \\
\hline Volume $\left(\mathrm{m}^{3}\right)$ & 17,622 & 19,590 & 14,998 & 137 & 137 & 132 \\
\hline Peak flow $(1 / \mathrm{s})$ & 150.07 & 166.85 & 127.78 & 1.65 & 1.65 & 3.6 \\
\hline
\end{tabular}

Table 10: Stormwater controls performance for retrofitting scenarios during continuous rainfall simulation (reference year: 2015).

\begin{tabular}{|l|c|c|c|c|}
\hline & $\mathrm{S} 1$ & $\mathrm{~S} 2$ & $\mathrm{~S} 3$ & $\mathrm{~S} 4$ \\
\hline Total inflow $(\mathrm{mm})$ & 2,335 & $75,866.31$ & $75,866.31$ & $104,794.49$ \\
\hline Surface outflow $(\mathrm{mm})$ & 0 & 0 & 0 & $1,891.34$ \\
\hline Outflow reduction $(\%)$ & $100 \%$ & $100 \%$ & $100 \%$ & $98 \%$ \\
\hline Infiltration loss $(\mathrm{mm})$ & 398 & $62,112.37$ & $62,076.9$ & $82,488.04$ \\
\hline Initial storage $(\mathrm{mm})$ & 30 & 600 & 600 & 577.5 \\
\hline Final storage $(\mathrm{mm})$ & 30 & $3,186.21$ & $3,188.98$ & $8,256.65$ \\
\hline
\end{tabular}

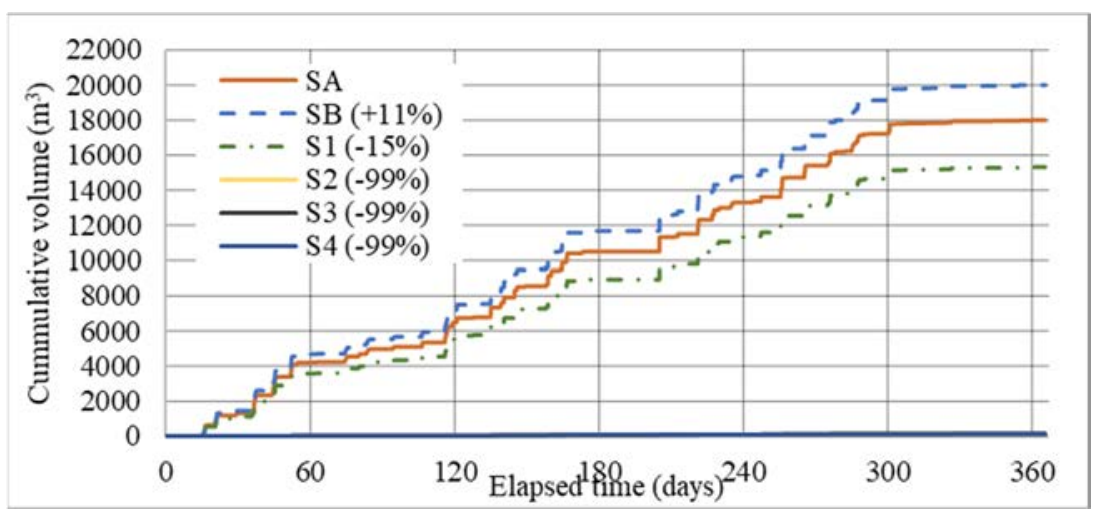

Figure 2: Cumulative volume for the continuous rainfall simulation (reference year: 2015) for initial scenario (SA), post-intervention (SB) and retrofitting (S1, S2, S3, S4). $\mathrm{S} 2, \mathrm{~S} 3$ and S4 don't generate outflow volume, so the cumulative volume curves are equal to the horizontal lines with ordinates equal to 0 .

Continuous simulation was also undertaken for November-December/2014 (Lambrate rain gauge), typically wet season with a particular series of events in that year that caused intense flooding. Table 11 presents volume and peak flow. The period registered a total rainfall depth of $\mathrm{ht}_{\mathrm{ot}}=756 \mathrm{~mm}$ and maximum rainfall intensity of $i_{\max }=90 \mathrm{~mm} / \mathrm{h}$. The effect of concatenated rainfall events, where the controls storage capacity where not completely available at the beginning of a new rainfall event, reduce their performance (Table 12). PP (S1) did not generate surface runoff for the previous simulations (Tables 6 and 10) but generate $33.36 \mathrm{~mm}$ of surface outflow for the November-December/2014 period (Table 12). The controls structures that rely on smaller infiltration areas like BG and RG presented a poor performance with a series of rainfall events. Fig. 3 shows the cumulated volume and volume reduction comparing with the initial scenario (SA). With respect to previous scenarios (Fig. 2) the poor performance of control systems leads to a smaller volume reduction. 
Table 11: Volume and peak flow for continuous rainfall simulation November-December 2014.

\begin{tabular}{|l|c|c|c|c|c|c|}
\hline & \multicolumn{7}{|c|}{ Scenarios } \\
\hline & SA & SB & S1 & S2 & S3 & S4 \\
\hline Volume $\left(\mathrm{m}^{3}\right)$ & 18,250 & 20,011 & 15,606 & 6,326 & 7,799 & 6,727 \\
\hline Peak flow $(1 / \mathrm{s})$ & 641 & 697 & 551 & 507 & 480 & 402 \\
\hline
\end{tabular}

Table 12: Stormwater controls performance for retrofitting scenarios for NovemberDecember 2014.

\begin{tabular}{|l|c|c|c|c|}
\hline & S1 & S2 & S3 & S4 \\
\hline Total inflow $(\mathrm{mm})$ & 2,267 & $72,974.53$ & $72,974.53$ & $100,843.5$ \\
\hline Surface outflow $(\mathrm{mm})$ & 0 & $19,388.11$ & $24,414.61$ & $39,028.6$ \\
\hline Outflow reduction $(\%)$ & 100 & 73 & 66.5 & 61.3 \\
\hline Infiltration loss $(\mathrm{mm})$ & 1,752 & $47,866.41$ & $42,819.25$ & $50,224.02$ \\
\hline Initial storage $(\mathrm{mm})$ & 30 & 600 & 600 & 577.5 \\
\hline Final storage $(\mathrm{mm})$ & 30 & $4,732.03$ & $4,668.64$ & $9,411.04$ \\
\hline
\end{tabular}

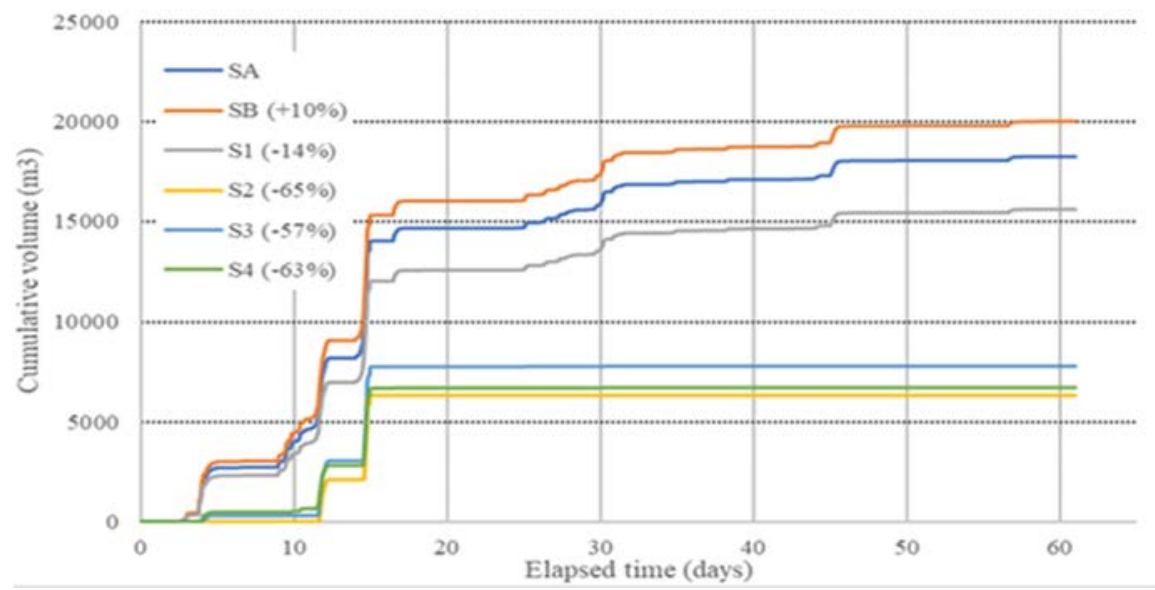

Figure 3: Cumulative volume for the continuous rainfall simulation for NovemberDecember/2014 for initial scenario (SA), post-intervention (SB) and retrofitting (S1, S2, S3, S4).

\section{CONCLUSION}

As a start-up for a research project on stormwater management and river restoration on the Seveso River basin, retrofitting scenarios were proposed for the densely urban area of the Bresso municipality, part of the Milan metropolitan area. The controls were pre-designed with a design-storm approach and then synthetic storms and continuous simulations were used to evaluate their performance and compare the scenarios proposed.

Efficiency of control structures on reducing runoff and meeting regional flow-limit regulations were discussed highlighting the importance of combining various types of control structures. Combination of controls present in each land use (rooftops, parking lots, roads,) gives better performance on volume and peak flow reduction. 
Some ponding from the control structures were observed with continuous simulation. Traditional storm-design approach and rainfall-runoff and flow routing simulation with synthetic storm does not represent the effect of two close rainfall events that significantly reduces stormwater storage controls performance. To proceed with continuous simulation or design methods instead of the probabilistic approach allows better representation of the effects of pre-filling.

The following up on this research will further detail the controls performance considering the additional benefits on biodiversity, climate resilience and including stormwater load partitioning performance, a critical issue for the Seveso River that struggles to meet the European Union river quality standards for state members.

\section{REFERENCES}

[1] Becciu, G., Ghia, M. \& Mambretti, S., A century of works on River Seveso: From unregulated development to basin reclamation. International Journal of Environmental Impacts, pp. 461-472, 2018. DOI: 10.2495/EI-V1-N4-461-472.

[2] Regolamento regionale 23 novembre 2017 n.7, Regolamento recante criteri e metodi per il rispetto del principio dell'invarianza idraulica ed idrologica ai sensi dell'articolo 58 bis della legge regionale 11 marzo 2005, n. 12 (Legge per il governo del territorio). https://www.regione.lombardia.it (in Italian).

[3] Becciu, G. \& Raimondi, A., Probabilistic analysis of the retention time in stormwater detention facilities. Procedia Engineering, 119, pp. 1299-1307, 2015. DOI: 10.1016/j.proeng.2015.08.951.

[4] Becciu, G. \& Raimondi, A., Probabilistic analysis of spills from stormwater detention facilities. WIT Transactions on the Built Environment, vol. 139, WIT Press: Southampton and Boston, 2014. DOI: 10.2495/UW140141.

[5] Becciu, G. \& Raimondi, A., Probabilistic modeling of the efficiency of a stormwater detention facility. International Journal of Sustainable Development and Planning, 10(6), pp. 795-805, 2015. DOI: 10.2495/sdp-v10-n6-795-805.

[6] Raimondi, A. \& Becciu, G., Probabilistic modeling of rainwater tanks. Procedia Engineering, 89, pp. 1493-1499, 2014. DOI: 10.1016/j.proeng.2014.11.437.

[7] Becciu, G., Raimondi, A. \& Dresti, C., Semi-probabilistic design of rainwater tanks: A case study in Northern Italy. Urban Water Journal, 15(3), pp. 192-199, 2018.

DOI: 10.1080/1573062X.2016.1148177.

[8] Becciu, G. \& Dresti, C., Uncertainties in flow duration curves in anthropized catchments. WIT Transactions on Ecology and the Environment, vol. 199, WIT Press: Southampton and Boston, pp. 123-134, 2015. DOI: 10.2495/RAV150111.

[9] Raimondi, F., Dresti, C., Marchioni, M.L., Kian, D., Mambretti, S. \& Becciu, G., Integrated strategies for river restoration and land re-naturalization in urban areas: A case study in Milan. WIT Transactions on the Built Environment, vol. 194, WIT Press: Southampton and Boston, pp. 23-34, 2020. DOI: 10.2495/FRIAR200031.

[10] Progetto Strategico di Sottobacino del torrente Seveso. www.contrattidifiume.it.

[11] Marchioni, M. \& Becciu, G., Experimental results on permeable pavements in urban areas: A synthetic review. International Journal of Sustainable Development and Planning, 10(6), pp. 806-817, 2015. DOI: 10.2495/SDP-V10-N6-806-817.

[12] Raimondi, A. \& Becciu, G., Performance of green roofs for rainwater control. Water Resources Management, 35, pp. 99-111, 2021. DOI: 10.1007/s11269-020-02712-3.

[13] Rizzo, A. et al., Constructed wetlands for combined sewer overflow treatment: A stateof-the-art review. Science of the Total Environment, 2021.

DOI: 10.1016/j.scitotenv.2020.138618. 
142 Sustainable Water Resources Management XI

[14] Raimondi, A. \& Becciu, G., On pre-filling probability of flood control detention facilities. Urban Water Journal, 12(4), pp. 344-351, 2015. DOI: 10.1080/1573062X.2014.901398.

[15] Rossman, L.A., Storm Water Management Model User's Manual, version 5.0. National Risk Management Research Laboratory, Office of Research and Development, US Environmental Protection Agency: Cincinnati, p. 276, 2010. 